\title{
Annular pancreas associated with duodenal obstruction
}

\author{
${ }^{1}$ Department of Pediatric Radiology, University Children's Hospital, Basel, Switzerland \\ ${ }^{2}$ Department of Pediatric Surgery, University Children's Hospital, Basel, Switzerland
}

Michele Pansini, ${ }^{1}$ Olaf Magerkurth, ${ }^{1}$ Frank-Martin Haecker, ${ }^{2}$ Sergio B Sesia ${ }^{2}$

Correspondence to Dr Sergio Sesia, sergio.sesia@ukbb.ch

\section{DESCRIPTION}

A preterm neonate weighing $1360 \mathrm{~g}$ was born at $33+2$ weeks' gestation with severe polyhydramnios. She was transferred, directly after delivery, to our neonatal intensive care unit presenting with distended upper abdomen and vomiting. A plain film of the abdomen (figure 1) was performed with the suspicion of duodenal atresia and showed a markedly distended stomach (S) and proximal duodenum (D) with no evidence of bowel gas distal to the duodenum. This finding, known as double bubble sign, is pathognomonic for a number of pathologies that cause duodenal obstruction, for example, duodenal web, duodenal atresia, midgut volvulus or annular pancreas ${ }^{1-3}$. At laparatomy (figure 2) the stomach (black arrowheads) and the duodenum were markedly dilated due to a complete annular band of pancreatic tissue that surrounded and constricted the second part of the duodenum (white arrows); distal to this site, the jejunum (black arrows)

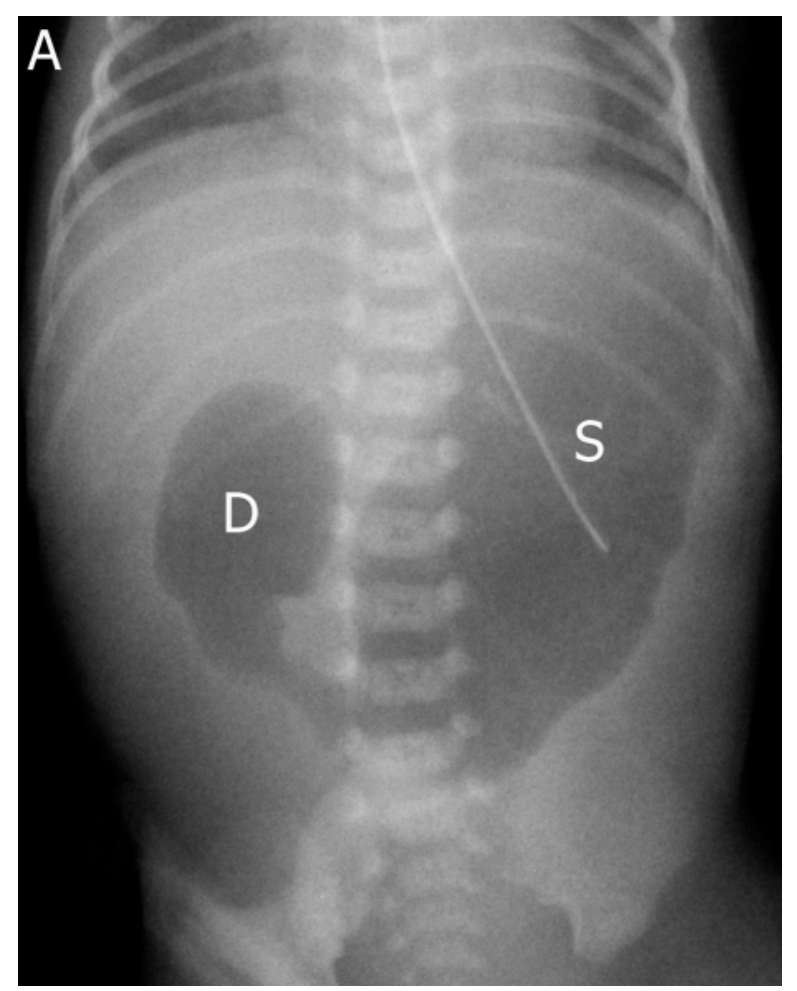

Figure 1 Plain x-ray of the abdomen: distended stomach (S) and proximal duodenum (D) with no evidence of bowel gas distal to the duodenum.

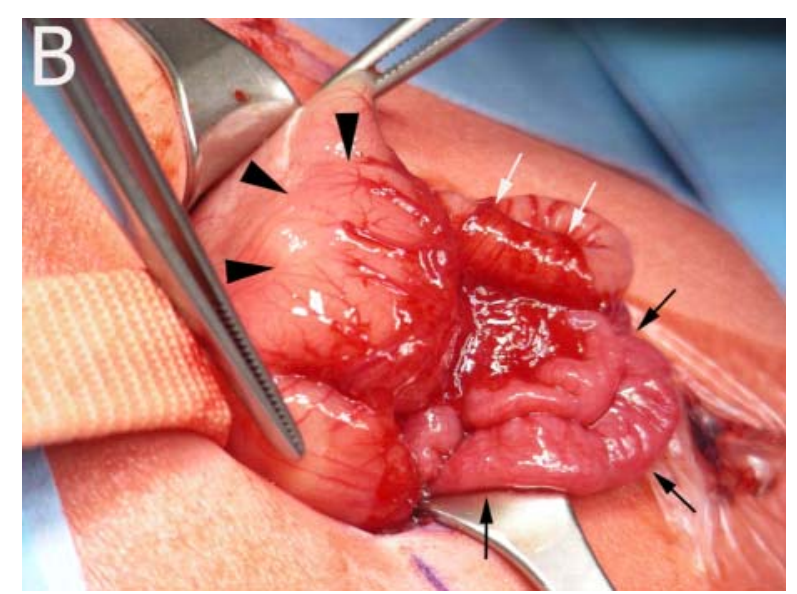

Figure 2 Intraoperatively: dilation of the stomach (black arrowheads) and the duodenum due to a complete annular band of pancreatic tissue that surrounded and constricted the second part of the duodenum (white arrows); distal to this site the jejunum (black arrows) was collapsed and atrophic.

was collapsed and atrophic. A duodenoduodenostomy was performed without any postoperative signs of gastrointestinal obstruction.

\section{Learning points}

- First clue of an intestinal atresia will often be finding hydramnios on prenatal ultrasound.

- Following delivery, vomiting is most common early symptom.

- Double-bubble sign on postnatal plain x-ray without evidence of distal gas is essentially pathognomonic for duodenal atresia.

Competing interests None.

Patient consent Obtained.

\section{REFERENCES}

1. Yang HC, Chen SJ, Liu KL. Double bubble sign. Emerg Med J 2011;28:1084.

2. Mortelé KJ, Rocha TC, Streeter JL, et al. Multimodality imaging of pancreatic and biliary congenital anomalies. Radiographics 2006;26:715-31.

3. Etienne D, John A, Menias CO, et al. Annular pancreas: a review of its molecular embryology, genetic basis and clinical considerations. Ann Anat 2012;194:422-8. 


\section{BMJ Case Reports}

This pdf has been created automatically from the final edited text and images.

Copyright 2012 BMJ Publishing Group. All rights reserved. For permission to reuse any of this content visit http://group.bmj.com/group/rights-licensing/permissions.

BMJ Case Report Fellows may re-use this article for personal use and teaching without any further permission.

Please cite this article as follows (you will need to access the article online to obtain the date of publication).

Pansini M, Magerkurth O, Haecker F-M, Sesia SB. Annular pancreas associated with duodenal obstruction. BMJ Case Reports 2012;10.1136/bcr-2012-006855, Published XXX

Become a Fellow of BMJ Case Reports today and you can:

- Submit as many cases as you like

- Enjoy fast sympathetic peer review and rapid publication of accepted articles

- Access all the published articles

- Re-use any of the published material for personal use and teaching without further permission

For information on Institutional Fellowships contact consortiasales@bmjgroup.com

Visit casereports.bmj.com for more articles like this and to become a Fellow 